релігійними та політичними суб’єктами різних рівнів; налагодження взаємодії між ними обумовлюють особливу роль таких форм інформації, як знання, досвід, культи, вірування, традиції, формування цілей об’єднання етносів в українську (політичну) націю, створення коду національного самозбереження, національних уявлень тощо.

У подальших дослідженнях слід визначити типологічні характеристики організації релігійно-політичних взаємодій в етнонаціональному процесі.

\title{
Анотації
}

У статті О.Бортнікової «Релігійні та політичну організації...» досліджено різні підходи до визначення сутності релігійних і політичних організацій як суб’єктів етнонаціонального процесу та їх ролі у функціонуванні й розвитку суспільства. Здійснено спробу охарактеризувати основні методологічні положення щодо розкриття природи релігійних і політичних суб'єктів як структурних елементів етнонаціональної системи, виявлення різних рівнів їх розміщення в умовах суспільних змін. Ключові слова: релігія, політика, організація, суб’єкт етнонаціонального процесу, релігійно-політичний простір.

\section{Olena Bortnikova. Religious and political organizations as subjects of national processes in Ukraine}

In the article the different approaches to defining the essence of religious and political organizations as subjects of national processes and their role in the functioning and development of society. Attempted to characterize the basic methodological provisions for disclosure of the nature of religious and political actors as structural elements of ethnonational system, identifying different levels of accommodation in terms of social change.

Key words: religion, politics, organization, process an ethnic, religious and political space.

\section{2 Ольга ГОЛЬД. Влияние церквных институций США на украинскую религиозную ситуацию.}

О религиозном влиянии США на Украину не так много написано. Но эта тема постоянно вызывает интерес в научных кругах ${ }^{98}$. Историки и религиоведы изучают появление американских религий на территории Украины, отмечая, что эти процессы по времени совпадают с общеевропейскими событиями. В Украину американские религии заходили не напрямую, а через Голландию, Польшу, некоторые другие европейские страны. Торговля предметами благосостояния, растениями и другими товарами стала и путем распространения религиозных идей, что дает нам еще один тезис в пользу жизнеспособности консюмеризма. Украина ощутила влияние идей американского федерализма и свободы религий, которые имели влияние на украинских мыслителей, в частности на Т.Шевченка, который, как известно, ожидал нашего Вашингтона «3 новим і праведним законом?» ${ }^{99}$.

Опыт США в сфере свободы религии имеет прежде всего историческое значение. Исследовательница американизации Европы К. Мак-Доннел обращает внимание на появление первых американських протестантских деноминаций в Западной Европе прежде всего в Париже в 1814 г. Подобные конгрегации появились позже в Берлине и Вене. Все эти организации действуют и сейчас, но, по мнению автора, большого влияния на социум Западной Европы не имели и не имеют, так как были созданы именно для американцев. Ревивалисты, прибывшие в Старый Свет, формировали пути, которыми американские деноминации несли свою веру в Европу (этот паттерн действует и сейчас).

Классический подход американцев в зарубежных странах - это скорее выбор идентичности, нежели традиционная религиозная община. Американские представители церкви тяготеют к созданию больших публичных собраний, речь обычна, проста и доступна, часто используют новейшие технологии - как католики, так и протестанты. Ссылки направлены индивидуально, то, что проповедники говорят обычно выразительно и сжато,

\footnotetext{
${ }^{98}$ См.: Филипович Л. Американізація релігійного життя України як прояв трансформаційних процесів глобалізованого світу // Релігійна свобода. .№8: Функціонування релігії в умовах свободи ії буття. - К., 2004. С.116-127; Гольд О.Ф. Американизация в религиозной жизни современной Украины // Культура народов Причерноморья. - 2011. -№ 209. - С. 115- 118.

99 Шевченко Тарас. Вибрані твори у 6 т. - Т. 2. - К., 2003. - С. 258.
} 
может меняться в современном формате. Возможно, считает К. Мак-Доннел, это отражение духа американской демократии в религии ${ }^{100}$.

По статистическим данным, приведенным в упоминаемом сборнике «Экспорт религии...», среди почти 30 тыс. (29785) зарегистрированных в Украине на 01.01.2004 г. религиозных организаций, тех, что мы относим к т.н. «американским» религиям, насчитывалось 1052, не учитывая религиозных миссий. Год от года количество новых течений вообще и американских в частности постепенно растет: если в 1995г. фиксировалось только 1\% зарегистрированных неорелигиозных организаций, то в 2000 г. их было уже почти 3\%, в 2004 г.- почти 5\%. Л. Филипович в 2004 г. давала прогноз: через 15-20 лет количество новых религий в Украине может составить до 10\% всех религиозных организаций в стране. Однако, по прошествии 7 лет после данной публикации, можно отметить, что (согласно опубликованным данным в «Религиозной панораме» за 2011 г.), так называемых «американских» религий в Украине насчитывается 2450 организаций, не учитывая миссий и т.н. «других религиозных течений», которые не вошли в вышеназванный список. Это показывает более стремительный рост количества американских религиозных организаций, что превышает темпы прогноза ${ }^{101}$. Хотя, с другой стороны, можно говорить, что к американским относятся не только новые, но и издавна действующие в Украине религии.

Как считает украинский исследователь свободы совести М.Ю. Бабий, «украинское государство, учитывая религиозно-плюральное своеобразие, сложившееся в обществе, негативные процессы в религиозной жизни (привнесенные, в частности, феномен нетрадиционности) в контексте тех демократических, социально-политических изменений, которые происходят, стремится: обеспечить полноценную свободу религиозного бытия человека, религии и церкви, правовой статус последних; создать благоприятные условия для полноты их деятельности и религиозной самоактуализации верующих; минимизировать проблемы в религиозной среде, снизить порог межконфессиональной нетерпимости» ${ }^{102}$.

Как известно, религиозный плюрализм в самих США стал одним из решающих моментов в становлении религиозной свободы. И таких параллелей в истории и нынешних Соединённых Штатах и Украины можно найти предостаточно для того, чтобы утверждать возможность восприятия нашей страной того позитивного опыта, что накопили американцы в других сферах социального воспроизводства. Хронология появления религиозных организаций американского происхождения, которую мы подаем, показывает те вехи американизации, которые коснулись и Украины. Эта история важна для нашего исследования, так как с религиозными организациями в Украину приходили ценности американского общества, что является само по себе процессом американизации религиозного сегмента украинского социума.

Адвентизм - сегодня это одна из многочисленных протестантских конфессий в Украине. Как известно, адвентизм возник в 40-х гг. в США в среде баптистов, методистов и последователей других деноминаций. «В Украине адвентизм появился в 1847 г. в Черновцах, где проповедовал М. Чеховский. В 1876 г. в Ровенской области возникла первая небольшая группа верующих. 1886 г. - пастор Луи Конрад крестил в Крыму группу людей, которые создали первую общину АСД. 1898 г. - Л. Конрад возглавил Европейскую Унионную Конференцию. 1906г. - общины АСД официально признаны в Российской империи. С 1931 г. - организация АСД была репрессирована советской властью После Второй мировой войны в Украине деятельность общин АСД была возобновлена.

После 1990 г. Церковь АСД на территории СНГ (бывшего СССР) была организована в Евро-Азиатский дивизион, который является XII частью территориального деления Всемирной Церкви. Сегодня в Украине действует Украинская Унионная Конференция,

\footnotetext{
100 Экспорт религии, трансляция веры: американские религиозные влияния в Европе /сборник/. - К.: Фулбрайт, 2004. - C. 3-5.

101 Статистика религиозных организаций: - [электронный ресурс] - режим доступа: http://old.risu.org.ua/rus/resourses/statistic

102 Экспорт религии, трансляция веры: американские религиозные влияния в Европе. - С. 88.
} 
состоящая из 8 региональных конференций, более 1050 общин. В Киеве действует Духовная семинария АСД. Сейчас офис Генеральной Ассамблеи находится в штате Мэриленд (США). Сегодня Адвентизм Седьмого Дня - это мощное религиозное движение всемирного масштаба, которое «имеет свои церкви в 220 из 236 стран, признанных ООН.

Баптизм на территории Украины имел своих сторонников еще с периода отмены в 1861 году крепостного права в Российской империи. Одним из первых баптистов в Российской империи считается крестьянин Онищенко из деревни Основа Одесского уезда. «В 1991 г., после ликвидации Всесоюзного совета евангельских христиан-баптистов для поддержания духовного общения евангельских христиан-баптистов стран бывшего СССР и для взаимной помощи между Союзами ЕХБ новых независимых государств, создана ЕвроАзиатская федерация союзов евангельских христиан-баптистов - объединение союзов евангельских христиан-баптистов стран СНГ» ${ }^{103}$.

Двадцать вторым съездом (8-11 февраля 1994 г.) был принят новый Устав и восстановлено название «Всеукраинский Союз Объединений евангельских христиан баптистов» (ВСО ЕХБ). Решением 25-го съезда (10-13 мая 2006) название было изменено на «Всеукраинский Союз Церквей евангельских христиан баптистов» (ВСЦ ЕХБ). У этой организации есть Европейский и Всемирный центры, последний находится в США.

Распространение пятидесятничества в Украине началось в начале XX в. Еще в 1911 г. жители с. Быковцы на Тернопольщине, П. Ильчук, Й. Антонюк, Т. Нагорный вместе с другими односельчанами выехали на заработки в США. Там вступили в церковь пятидесятников. После окончания специальной миссионерской школы они, уполномоченные и финансово поддержанные, в 1919 г. вернулись и развернули широкую миссионерскую и проповедническую деятельность. Вскоре пятидесятническая община возникает в с. Быковцы, а в 1923г.- в г. Кременце. Здесь в мае 1924 г. под управлением подготовленного в США украинского миссионера И. Гериса проведен Первый съезд пятидесятников Западной Украины. Был принят устав, утверждены правила внутрицерковной жизни, разработана догматика, были намечены планы проповедническо-миссионерской деятельности» ${ }^{104}$.

В 1920 году в Одессу прибыли посланники пятидесятников США И.Е. Воронаев (ему установлен памятник в Одесской цепкви) и В.Р.Колтович. Они активно действовали до начала репрессий советских времен. В целях активизации миссионерства среди славянских народов еще одна пятидесятническая церковь «Американская ассамблея Божья» в июне 1928 г. образовала специальную «Восточноевропейскую миссию». Пятидесятническому движению в Украине были даны новые импульсы» 105.

Настоящий расцвет пятидесятничества в СССР пришелся на 20-е гг. XX в. Большевики сначала довольно благосклонно относились к пятидесятникам, как и к другим гонимым царизмом конфессиям, которых считали «жертвами царского режима». Различные христианские группы (в том числе и пятидесятнические) обосновывались и развивались в СССР, многие приезжали в страну из США, устраивали сельскохозяйственные коммуны, открывали новые молитвенные дома по всей стране. Именно тогда возникли и сложились основные течения пятидесятничества: «Христиане Евангельской веры» (воронаевцы), «Христиане Веры Евангельской» (шмидтовцы), «Евангельские христиане в Духе Апостолов» (смородинцы), «субботствующие пятидесятники», «Евангельские христиане пятидесятникисионисты» (леонтьевцы). Позже появились «Евангельские христиане святые сионисты» и другие более мелкие течения. Все они развивались, укреплялись и пускали корни в СССР при одобрении власти. Главной их проблемой были они сами, потому что сами они катастрофически не могли уживаться друг с другом и продолжали делиться на новые и новые течения» ${ }^{106}$.

\footnotetext{
${ }^{103}$ Whaling F. Religion in today's world: The religions situation of the World from 1945 to the present day. - Edinburg: Clark, 1987.

${ }^{104}$ Історія релігії в Україні: у 10 т. / за ред. проф. А.Колодного. /Нові релігії України. - Т.8. - Київ, 2010.- C.386-389.

${ }^{105}$ Там само. - C.388

${ }^{106}$ Whaling F. Religion in today's world: The religions situation of the World from 1945 to the present day.
} 
В контексте нашего исследования необходимо обратить внимание на трагические обстоятельства, которые сопровождали становление пятидесятничества в Украине. Так, например, в 1924 г., свыше 50 общин организовали Областной союз христиан евангельской веры с центром в г. Одессе. 3 сентября 1925 г. был образован Всеукраинский союз ХЕВ, который тогда насчитывал больше ста общин. На время разрушения этого Союза в 1930-х годах в СССР насчитывалось свыше 500 общин и 25 тыс. Верующих пятидесятников. Председателем Союза был уже известный нам Иван Воронаев. После ликвидации Союза руководство погибло в концлагере. В 1939 г. Всепольский Союз христиан веры евангельской прекратил свое существование, а большое количество пасторов были репрессированы. В 1945 г. советская власть под угрозой новых репрессий предложила руководителям пятидесятников войти в Союз евангельских христиан-баптистов. Вследствие этого было подписано так называемое Августовское соглашение 1945 года. Многие церковные общины пятидесятников (как XBE, так и XEB), особенно в западных областях, вошли в это объединение и находились в нем до 1989 г.

Кроме того, в Украине действует ряд других пятидесятнических объединений, в частности: Союз вільних церков християн євангельської віри (111 - общин, 6 - центров, 10 миссии), Украинский центр Объединенной церкви христиан веры евангельской (который объединяет незарегистрированные общины) (123 - общин, 11 -центров, 6 - миссий), Союз Церкви Божьей Украины (82 - общин, 1 - центров, 1 - миссия) и другие. Вместе с тем свыше 200 пятидесятнических общин действуют как независимые ${ }^{107}$.

Сегодня в Украине действует несколько объединенных союзов свободных церквей христиан евангельской веры. ВСЦХВЕ(п) и СВЦХЕВ являются членами Всеукраинского Совета Церквей и религиозных организаций.

В 2011 году церкви, входящие в Международный Христианский Центр «Пробуждение», отмечали 90-летие Пятидесятнического движения на постсоветском пространстве. Программа празднования проходила в несколько этапов по всему миру. Цикл празднований открылся 19 марта в г. Сакраменто (США). Мероприятия в Одессе проводились 7-11 сентября. В эти же дни состоялась конференция служителей Объединения «Пробуждение», включавшая и ряд других мероприятий. В Одессе открыт памятник «Сподвижникам веры» - первый в истории евангельского движения Украины памятник погибшим за веру евангельским христианам. Также был открыт в Одессе музей рассекреченных бумаг КГБ и «Музей под открытым небом», где была представлена репродукция ветхозаветной Скинии. Кроме всего этого, интересна была проведена обзорная экскурсия по Одессе «По следам Воронаева», проповедника и миссионера, основателя Пятидесятнического движения в странах бывшего СССР. А также состоялись праздничные мероприятия и богослужения в разных исторических зданиях Одессы, в т. ч. в Лютеранской кирхе и Оперном театре ${ }^{108}$.

Религиозное движение «Исследователей Библии» с 1932 г. получило название «Свидетели Иеговы». Ч. Рассел, один из основателей этого движения, побывав с целью привлечения новых последователей в Петербурге, Кишиневе, Варшаве и в других европейских городах, посетил также и Львов, где прошел первый конгресс течения.

Особое внимание миссионерской деятельности в Восточной Украине, которая была в составе СССР, оказывал американский Бруклинский Центр «Международного общества исследователей Библии». «Еще в начале 1900-х гг. исследователь Библии Трумпи из Швейцарии приехал как инженер на Донбасс. Он был первым из известных нам «исследователей Библии» в этой местности в условиях советской власти. В 1920-х годах благодаря его деятельности в селе Любимовський Пост, что близ Харькова, образовалась община «Исследователей Библии». В 1927 г. начали приезжать другие миссионеры движения «Исследователей Библии» из Западной Европы, чтобы работать инженерами на шахтах или,

\footnotetext{
${ }_{107}$ Статистика рел. орг.: - [электронный ресурс] - режим доступа: http://old.risu.org.ua/rus/resourses/statistic 108 Одесса отметит Пробуждение: [электронный доступа:http://www.misto.odessa.ua/index.php?=novosti/odessa/nom,31222
} 
как говорил Иисус Христос, «ловцами душ человеческих», т.е. активными распространителями идей «Исследователей Библии». Уже в 1927 г. ими было создано несколько общин верующих» ${ }^{109}$.

Кроме христианских церквей, на территории Украины под влиянием американских центров более 20 лет распространяются современные течения иудаизма. Очень интересно, что такое направление иудаизма как хасидизм, частично возникший на территории Украины в первой половине XVIII в., пережил свое второе рождение в нашей стране в 90 -е годы XX в. под влиянием американских центров. Сегодня в Украине действуют около 108 общин и 2 центра этого религиозного направления.

В Украине действует также и религиозная организация прогрессивного иудаизма, куда относятся реформистская и консервативная ветви. Это направление начало действовать также с 1990 годов. Всего по Украине 41 община и 1 центр организации прогрессивных иудеев. На 2016 г. вышел из общего состава Крим и Восток Украины. «Реформистский иудаизм» (сокращенно - реформизм) - движение за обновление иудаизма, которое возникло в Германии во втором десятилетии XIX в. Оттуда распространилось на другие страны Центральной и Западной Европы, чем вызвал брожение в еврейских общинах Восточной Европы. Во второй половине ХІХ в. главным центром движения становятся США» ${ }^{110}$.

Другое течение - консервативный иудаизм - возник как ответ на более либеральные позиции реформистского иудаизма. Началось это течение также во втором десятилетии XIX века, а более организованные его формы, как вторая волна, возникли в США в XX в.

Так называемая, «вторая волна» реформистского и консервативного иудаизма в Украине, является именно американским влиянием во второй половине XX в. В Украине сейчас существует целая сеть реформистских иудейских общин. Эти общины есть в Одессе, Киеве, Полтаве, Харькове и других городах. Сегодня в Украине действует Религиозное объединение общин прогрессивного иудаизма Украины (РООПИУ).

Следующая группа деноминаций американского происхождения из числа действующих в Украине, это харизматы. В харизматической Церкви Христа существует несколько групп, выступающих под этим общим названием. Как констатирует религиовед И.Козловский: «История движения Церкви Христовой в нашей стране насчитывает всего 18 лет (в 2008г.). Регистрация ее общин у нас началась еще в советское время в 1990 г.» ${ }^{111}$. Сейчас их 117, религиозных миссии- 2 и 4 учебных заведений. Первая из них возникла «в 1895 г., в Калифорнии (США). Это Церковь Назарянина, духовным пастором которой стал методистский пастор Ф.Ф. Бризли. В 1907 г. в городе Чикаго группа Бризли объединилась с церковью под руководством Рейнолдса, действовавшей у восточного побережья США. Первыми генеральными суперинтендантами были избраны Ф. Бризли и Г. Рейнолс» ${ }^{112}$.

Вторая харизматическая церковь возникает в 1965 г. под названием «Калвари Чапел» Голгофская часовня. Популярность Церкви распространилась за пределами Америки и в 1992 г. она была зарегистрирована в Украине. Сейчас в нашей стране существует центры Церкви Калвари Чапел в Днепродзержинске и Киеве. Церковь Дом Хлеба возникла в 1906 г. в Лос-Анджелесе. В 90-х годах пр.в. она стала религиозным течением, воспринятым славянской эмиграцией тех лет. В Украине эта церковь действует в Кривом Роге с 2001 г.. Сейчас, во многих крупных городах Украины открыты её миссионерские центры ${ }^{113}$.

К другому направлению американской религиозной активности в Украине можно отнести деноминации ориенталистского толка. В 1966 г. Шри Чин Мой образует общественно-образовательную организацию. Благодаря всемирным акциям культурного и спортивного характера, Шри Чин Мой достигает распространения своей философии. Центр Чинмоя регулирует распределение гуманитарной помощи, в том числе и в Украине. Сейчас

\footnotetext{
109 Экспорт религии, трансляция веры: американские религиозные влияния в Европе. - С. 33-38.

110 Там же.

111 Історія релігії в Україні /Нові релігії України. - Т.8.- С.356.

112 Там же. - C.375-376.

113 The Church About - Церковь Христова: [электронный ресурс] - режим доступа:http:// kievchurch.org.ua/
} 
главное управление центра находится в Нью-Йорке. В начале 90-х годов п.в. распространяется в Украине, где есть 3 его центра.

Международное общество сознания Кришны (МОСК) возникло вначале как Общество Гаудио-вайшнавов, которое предоставило Шриле Прабхупаде титул «Бхактиведанта». В 1965 г., после распечатки первых трех томов «Шримад - Бхагаватам», Прабхупада уехал в Соединенные Штаты выполнять миссию основателя Международного общества сознания Кришны ${ }^{114}$. Еще с 1971 г., после визита в Москву, началось распространение учения Прабхупады Свами Бхактиведанты в тогдашнем СССР. Это учение имело свои общины во многих регионах Советского Союза, в том числе и в Советской Украине, где его сторонники подверглись репрессиям. В 1990 г. было зарегистрировано первую религиозную общину вайшнавов на Украине, в Киеве. Сейчас в Украине существует 42 организаций Сознания Кришны и 1 проповеднический центр «Харе Кришна - Пища жизни». В 1993 г. был создан Центр обществ Сознания Кришны в Украине, а также было зарегистрировано Духовную академию Сознания Кришны. Сейчас в нашей стране Общество насчитывает примерно 43 священнослужителей.

«Христианская наука» была основана под руководством Мэри Бейкер Эдди в 1876 г. в городе Линн, в штате Массачусетс (США). В России церковь появилась в 1906 г., но лишь в 1924 г. организация была официально зарегистрирована в советской России. В 1928 г. церковь была распущена властями. Теперь центр Материнской Церкви «Христианская наука» находится в Бостоне (штат Массачусетс). В Украине существует с 1990-х г. филиал Первой научной Церкви Христа в городе Херсон.

Одной из самых динамичных церквей американского происхождения сейчас является Церковь Иисуса Христа Святых последних дней (ЦИХСПД) или мормонов. Она есть во многих странах мира, где последователей церкви уже больше, чем в Штатах, а количество их вообще, достигло около 15 миллионов. Украинский религиовед А. Н. Колодный обращает внимание на тот факт, что: «Первые миссионеры ЦИХСПД прибыли в Европу еще в 1837 р., но в украинском социуме они появились лишь в 1990 г., в годы перестройки, когда страна стала уже относительно открытой для мирового сообщества и двигалась к своей независимости. В январе 1990 г.в Киев приехали старейшины Д. Ноешвандер и Л. Карсон с целью изучения возможностей деятельности Церкви в украинских условиях. Первые миссионеры появились в Украине 7 октября этого же года. Ими были Б. Брэдбери из США и И. Стратов из Австралии. Вскоре состоялось собрание ее сторонников, где присутствовало всего двадцать человек. 25 ноября в Днепре были окрещены первые граждане Украины по мормонскому обряду» ${ }^{115}$.

Первая община ЦИХСПД открыто заявила о своем существовании в Украине в июне 1991 г. Зарегистрирована она была государственными органами уже в сентябре. С этого времени на украинских просторах появляются все новые и новые общины-филиалы мормонов. Ещё на начало 2004 г. мормоны насчитывают в Украине около 10 тыс. человек. Также был решен вопрос об образовании в Украине такой структурной единицы Церкви как «кол», построение в Киеве ее храма. В 2010 г. был открыт первый в Восточной Европе храм в Киеве. Сегодня в Украине действую 44 общин и 46 учебных заведений ЦИХСПД.

Миссия ЦИХСПД появилась в Киеве в феврале 1992 г. а в июле 1993 г. произошло отделение Донецкой миссии Церкви от Киевской. Госкомрелигии Украины в июле 1996 г. официально зарегистрировал Религиозное Управление Церкви Иисуса Христа Святых последних дней в Украине, расположенное в Киеве.

Организация «Евреи за Иисуса» (Jews for Jesus) была основана в 1973 г. Моше Розеном. Тогда же было открыто несколько филиалов организации в США. В 1980 х гг. Евреи за Иисуса вышли на международный уровень. Украинские и российские верующие смогли присоединиться только в 1990 х гг. В 1991 г. открылось первое представительство движения в Одессе. Теперь на территории Украины действует 4 общины конфессии, они

\footnotetext{
${ }^{114}$ Історія релігії в Україні: /Нові релігії України. - Т.8. - С.535.

115 Там же.
} 
расположены в Киеве, Харькове, Днепропетровске и Одессе. «По наблюдениям студентов НаУКМА, сейчас в среднем на рядовой шабат приходит около 30-35 человек. Собственно ядро общины, которое занимается организацией, состоит из 6 человек» ${ }^{116}$.

В конце прошлого века в нашей стране, благодаря американским миссионерам, состоялось возрождение пресвитерианства. 12 апреля, 1992 г., когда было зарегистрировано две первые общины в г. Ровно и г. Степан, началось движение Евангельской Реформатской Церкви Украины. В разных городах начали создаваться новые пресвитерианские общины. Так, в Одессе удалось реанимировать утраченную конфессию, зарегистрировав ее вновь, только в 1996 г. (Евангельская Пресвитерианская Церковь Одессы). Верующие нашли поддержку от единоверцев из Америки, там, где в ее состав входят около 1600 церквей, действующих во всех штатах Северной Америки и в Канаде. Сегодня в Украине 62 общин и 3 центра пресвитериан.

На последнее десятилетие XX в. приходится и появление в нашей стране такой американской деноминации как «Церковь саентологов». Как считает исследователь А. Саган, «появление в Украине Церкви саентологии стало возможным лишь после обретения страной независимости и установления здесь базовых принципов свободы совести. Но даже после открытия страны для миссионерской деятельности саентологи не сразу заявили о себе. Первые две общины саентологов были зарегистрированы в 1995 г. В 1997-1999 рр. их было зафиксировано еще три. В 2001-2002 гг к ним добавилась одна не зарегистрированая община, однако в 2004 г.в статистике почему-то учитывалась лишь одна община» ${ }^{117}$.

Сейчас в Украине действуют три саентологических центра - Киевский, Одесский и Харьковский (это гуманитарные центры Хаббарда), а также несколько саентологических общин. В октябре 2010 г. состоялся переезд одесской общины в новое здание, что, на наш взгляд, может служить свидетельством о расширении её влияния, по крайней мере, на Юге нашей страны.

В 2005 г. в Украине официально была открыта ещё одна церковь американского происхождения - Религиозная Община Епископальной Церкви. Три церкви (в городе Каховка, в селе Любимовка и в селе Малокаховка) зарегистрированы. Есть еще и незарегистрированные общины. Кроме двух епископов, в Церкви служат пять священников и шесть диаконов).

Еще одна церковь появилась в Америке в кругу украинских эмигрантов. В 1934 г. профессор В. Шаян основывает неоязыческое генотеистическое течение Родная Вера. Другой неоязыческий культ - Родная Украинская Национальная Вера (РУНВира) - основал Лев Силенко после Второй Мировой войны среди украинской диаспоры. Символом приверженцев РУНВеры является тризуб, как национальный герб. Основные положения Рунверы изложены в работе Л. Силенко «Мага-вера». Центр РУНВеры - собор святой матери - Украины - расположен в г. Спринг Глен (штат Нью-Йорк, США). Первая община была зарегистрирована в Украине в 1991 г.

Процесс заимствования религий американского происхождения продолжается и в XX1 в. В основном, они представлены как пародийные религии в интернете. В течении последнего десятилетия в Украине появились сведения о движении трансгуманистов, последователях Чайника Рассела и церкви Невидимого Розового Единорога.

В начале 2010 г. появились первые последователи Украинской Пастафарианской Церкви (Макаронные Приходы или УПЦ). Эти религиозные движения возникли в США в 1952 г., 1990 г. и. в 2005 г. соответственно.

Сторонники церквей Невидимого Розового Единорога и убеждения Чайника Рассела и других современных пародийных религиозных форм, возникших в США, преимущественно общаются только в сети либо на собраниях в собственных квартирах.

Украинская Пастафарианськая Церковь (Макаронные Приходы), сокращенно - УПЦ МП, или просто УПЦ имеет свой независимый сайт, а также представлена в Живом

\footnotetext{
${ }^{116}$ Історія релігії в Україні /Нові релігії України. - Т.8.- С.776.

117 Экспорт религии, трансляция веры: американские религиозные влияния в Европе. - С. 56.
} 
Журнале. Источники церкви сообщили, что церковь намерена в будущем выйти из интернета и открыть свое реальное представительство ${ }^{118}$.

Приведенные материалы позволяют заключить, что, американизация в Украине имела три этапа или так называемые «волны». Первая волна началась с приезда первых миссионеров и возникновения общин последователей Адвентистов Седьмого Дня в 1847 г. и продлилась почти до середины ХХ в. Вторая состоялась в военные годы с 1941 по 1945, когда США осуществляли разнообразную помощь СССР (вместе с помощью распространялся также позитивный образ Америки) и продлилась до середины 90 гг. XX в. Третья волна началась во времена перестройки, но именно пик ее пришелся на 1991 год, когда большинство из представленных в данной статье религий были импортированы в нашу страну и их распространение продолжается до сих пор. Можно также утверждать, что с распространением интернета в Украине получают распространение и on-line религии американского происхождения.

Исходя из представленной хронологии американизации в украинском социальнорелигиозном пространстве, заключим, что это явление в истории (приблизительно в полтора века), в той или иной степени стало неотъемлемой частью украинского общества. Некоторые проявления американизации настолько привычны, что их трудно выделить в современном обществе.

\section{3 Георгій ФИЛИПОВИЧ. Церква в діаспорі як чинник збереження історичної пам'яті українців.}

Актуальність $\boldsymbol{i}$ завдання. Визначаючи предметне поле такої нової ділянки історичної науки, як «історія пам'яті», відомий український історик Наталя Яковенко писала: «її метою $\epsilon$ вивчення того, як суспільства пам'ятають, а конкретніше, який образ минулого утверджується у колективній свідомості певної спільноти - зазвичай через меморіальні практики, мистецтво, пам'ятники героям чи певним подіям, назви вулиць, підручникову літературу тощо. Окремим аспектом таких досліджень є свідома кореляція такої пам'яті на потребу дня з боку держави чи речників відповідної ідеології...» ${ }^{119}$. Таке розуміння історичної пам'яті цілком лягає в назву і завдання даної статті, автор якої усвідомлює, що не зможе охопити всю сукупність донаукових, наукових, квазінаукових і ненаукових знань та масових уявлень про спільне минуле. Тому зупинимося на досвіді української церкви в діаспорі як речника не тільки релігійної, але й національної стратегії відтворення i збереження для українців закордоння.

Основний виклад. Аналізуючи цей досвід, такий багатий на різні ідеї і події, складається враження, що акумуляція і передача знань про минуле - ключова функція Церкви, яка щороку актуалізує історичної ваги дати: народження Ісуса Христа та Його воскресіння. Будучи основою релігійної самоідентифікації християнина та християнських спільнот, Церква прагне опредметити у відповідних культурних формах (традиціях, пам'ятках, мемуарах тощо) ці давні події, які живуть в історичній свідомості мільйонів. Тут Церква користується цілим арсеналом засобів, напрацьованих віками. Вони є продуктом певного часу і місця, постійно удосконалюються, адаптуючись до конкретної історичної ситуації. От такою ситуацією стала масова еміграція українців на захід наприкінці XIX ст., які взяли із собою і свою Церкву - гаранта і основний інструмент збереження історичної пам'яті.

\footnotetext{
118 Атеїзм в Україні: [электронный ресурс] - режим доступа: http://razum-org.at.ua/

119 Яковенко Н. «Лише наївний історик сліпо вірить джерелу, натомість фахово зрілий - ніколи» [Електронний pecypc]. - Режим доступу: http://science.platfor.ma/natalya-yakovenko/. - Назва з екрану
} 